\title{
Figures, Tables, and Learning Aids
}

\section{Figures}

1.1: Female deficiencies: Theoretical rationales 14

2.1: The entrepreneurial identity framework 39

3.1: Gendered matrix of venture creation 60

4.1: Export thresholds: Association between firm size and $\begin{array}{ll}\text { export propensity } & 72\end{array}$

4.2: Lessons learned and advice about exporting 91

5.1: Framework of social capital 105

5.2: Spheres of social capital 107

6.1: Framework of financial capital 128

7.1: Landscape of women's entrepreneurship and small-business programs

\section{Tables}

I.1: Gender and venture creation 5

1.1: Early masculine and feminine nomenclatures 12

1.2: Theoretical foundations of entrepreneurial feminism 20

3.1: Gender dimensions of sector "choice" 51

3.2: Gender perspectives on venture creation 58

3.3: Lessons learned from feminist entrepreneurs 63

6.1: Tensions in lending relationships 131

6.2: Leverage: Debt and equity investment 136

7.1: Global indices associated with women's entrepreneurship $\quad 147$

7.2: Approaches to assessing economic gender discrimination 158

7.3: Rationales for female-focused entrepreneurship policies 164

7.4: Strategies to make policy change happen 169

8.1: Strategies to support women's entrepreneurship 175 


\section{Learning Aids}

2.1: Recognizing your feminine capital 31

2.2: Building blocks of entrepreneurial success 35

2.3: Building blocks of entrepreneurial intention 41

3.1: Planned strategy 48

3.2: Managing startup ideas 49

3.3: Effectuation process versus planned strategy 55

4.1: Explanations of enterprise growth 76

5.1: Strategies to build trust in relationships 104

5.2: Sources and configuration of social capital 110

5.3: Learning expectations of mentoring 114

5.4: Tips for establishing a peer-to-peer mentoring group 115

5.5: Tips for building an advisory board 117

5.6: Should I add this association to my social capital portfolio? 119

6.1: Benefits and risks of external capital 138

6.2: Strategies to increase women entrepreneurs' access to capital 140

7.1: Women-focused entrepreneurship policy 153

7.2: Entrepreneurship policy levers 160

7.3: Motives for using female-focused entrepreneurship programs 166 